\title{
Soviet academy condemned for "lack of democracy"
}

\section{London}

ThE Soviet Academy of Sciences, which for decades has been praised abroad as the one remaining institution in the Soviet Union to preserve multi-candidate elections by secret ballot is now being attacked for its "lack of democracy". Comments by scientists in Literaturnaya Gazeta last week call the academy a "stronghold of obsolete thinking" and a "fortress against the democratization of scientific activity". The feature appeared on the same day that academy officials met to discuss "restructuring" and democratization - without, apparently, touching on the main cause of discontent.

The academy is not merely a selfelecting body of a few hundred eminent scientists; it is also one of the main employers of scientists in the Soviet Union, with a vast network of research institutions and a scientific work-force of tens of thousands. These scientist employees now wish to use the new 'democratization' drive to elect their own directors and heads of department, section or laboratory.

But the president of the academy, Dr Gurii Marchuk told Izvestiya last March that if the right of electing people to these posts is given to the scientific work-force, "it could lead to negative consequences". The collective may "appraise" the nominations for director, he said, but it is the scientific council of the institute that must decide.

Marchuk's remarks drew an angry reply from the scientific community. In an "open letter' published in Literaturnaya Gazeta, 22 eminent researchers pointed out that, under the current provisional statutes of the academy, the director "determines" the membership of the scientific council. As this council then elects the heads of department, such posts are usually filled by nominees of the directors.

The presidium of the academy has issued a formal reply saying that democratic traditions have long existed in the academy and will continue to be improved. A commission has been set up and will this month submit a programme to be discussed by the presidium, then handed down to the institutes' collectives for "broad discussion and the subsequent adoption of a definite decision in accordance with the academy's statutes". The institute director will continue to be elected by secret ballot at a general meeting of the relevant branch; the scientific council of each institute, subject to confirmation by the relevant branch and heads of department, will be elected by the work collectives; and at all levels, candidates for election must submit a proposal for the work to be carried out under their direction.
This, however, is not enough, according to the scientific editors of Literaturnaya Gazeta. They point out that the new Law on State Enterprises specifies that the enterprise leader is to be elected by the work collective. To deprive scientists of a right now enjoyed by workers and collective farmers is, the editors conclude, "simply offensive". Literaturnaya Gazeta has received numerous complaints from scientists about anti-democratic practices within the academy, a resumé of which has now appeared. Cases have been reported of "direct persecution" and "arbitrary behaviour" on the part of institute directors. A letter from A. Fedorov, a Moscow biologist notes that "institute directors are often chosen not for profes-

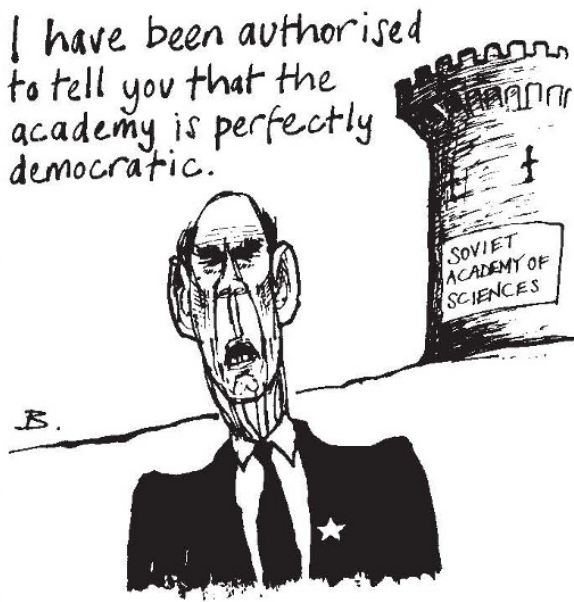

sional qualifications ... but on the basis of favouritism", and that once in an administrative post, they automatically move up the academic ladder until they become full members of the academy, with honorary titles.

Recently, when vacancies have arisen for institute directors, in virtually every case institute staff have demanded the right to elect them themselves. There have already been some dramatic battles and in at least one case the staff have managed to reject the official nominee and have their own choice appointed.

The basic difficulty appears to be the contrast between the academy's original role as a small, self-electing elite and its current function as the principal coordinator of scientific activity for the entire Soviet Union. Although this new role is regularly stressed in political exhortations, it has never been reflected in the academy statutes, which even in their latest revision state that "the Academy consists of Full Members and Corresponding Members", ignoring the thousands of scientists employed in academy institutes. And these scientists are unwilling to be ignored any longer.

\section{Production of recombinant insulin begins}

\section{Munich}

After a two-year delay, the West German Land (federal government) of Hesse on 9 September granted permission for Hoechst $A G$ to produce synthetic human insulin from genetically manipulated bacteria. This is the first time a factory dependent on recombinant bacteria has been approved in West Germany.

Synthetic insulin produced from bacteria causes fewer health problems than the pig insulin commonly used by diabetics. Using bacteria containing a human gene to produce insulin is not a new process; British and US companies have been doing it with little fanfare since 1982 . But West Germany's Green party has delayed government approval for part of the Hoechst production facility since 1985.

The insulin plant, thought to have cost Hoechst $\$ 60$ million, "included more safety provisions than we required", said Gerd Hobom of the Zentrale Kommission für Biologische Sicherheit (ZKBS), the government organization responsible for assessing the safety of genetic engineering procedures. The bacteria are held in a closed vessel with a built-in system to warn of leaks and are killed before they are removed from the fermenter for processing. The insulin-containing brew is heated once again to denature remaining DNA.

West Germany has no law regulating use of genetically altered organisms. Until now, researchers and companies have voluntarily called in the parent of the ZKBS, the Bundesgesundheitsamt (Federal Health Office or BGA) for a safety rating. The pharmaceutical industry organization has accepted the BGA's authority in this matter; all researchers funded by the federal or Länder governments are also required to comply.

But the situation will soon change. The Bundestag (federal parliament) has called on the Health Ministry to draft a law to regulate genetic engineering. Despite the opposition of some scientists who think self-regulation is enough, some version of the bill will probably pass in the coming year.

One other West German company, Boehringer Ingelheim, has used recombinant techniques to create a pharmaceutical product, in this case the heart drug TPA (tissue plasminogen activator; see Nature 327, 450; 1987). TPA is produced with mammalian cells in culture rather than with bacteria. Boehringer has already received unofficial approval for producing TPA at its plant in Biberach (which is not in Hesse); written approval is expected any day now. Steven Dickman 